\author{
Жовква Ольга Іванівна \\ доктор архітектури, доцент, \\ головний спеціаліст Департаменту \\ містобудування та архітектури \\ Київської міської державної адміністрації \\ ORCID 0000-0002-0086-6774 \\ glavarch@ukr.net
}

\title{
СИМВОЛІЧНИЙ ЗМІСТ САКРАЛЬНИХ ОБ'ЄКТІВ СВІТОВИХ РЕЛІГІЙ
}

\begin{abstract}
Мета роботи - розкрити духовно - релігійну метафорику, що наповнює архітектуру сакральних споруд світових релігій (Християнство, Іслам, Іудаїзм), а також змістове навантаження їх окремих фрорм і деталей в контексті канонічних та сакрально-релігійних вимог. Методологія дослідження. Базується на методі натурного обстеження сакральних споруд, розташованих як на території України так і закордоном, а також на історичному методі, який дозволив дослідити процес їх розвитку та фрормування в історичному контексті. За допомогою методу порівняльного аналізу визначені спільності та особливості об'ємно-просторової організації сакральних споруд світових релігій. Наукова новизна. Досліджено особливості архітектури християнських, мусульманських та іудейських сакральних споруд, а також змістове навантаження їх окремих форм та елементів в релігійносакральному контексті. Запропоновано принцип релігійної гармонійності та канонічності архітектурної композиції даних споруд. Висновки. На базі дослідження історичного і сучасного досвіду проектування та будівництва християнських, мусульманських та іудейських сакральних споруд визначено спільні риси архітектурної композиції (об'ємно-просторових рішень), а також змістового навантаження архітектурних форм, що випливає із релігійної догматики.
\end{abstract}

Ключові слова: сакральна (культова) споруда, канонічність, символіка фрорм, символ.

Жовква Ольга Ивановна, доктор архитектуры, доцент, главный специалист Департамента градостроительства и архитектуры Киевской городской государственной администрации

Символическое значение сакральных объектов мировых религий

Цель работы - раскрыть духовно-религиозное содержание сакральных сооружений мировых религий (Христианство, Ислам, Иудаизм) в контексте канонических и сакрально-религиозных требований. Методология исследования. Базируется на использовании метода натурного обследования отечественных и зарубежных сакральных сооружений, а также на историческом методе, что позволило изучить процесс развития в историческом контексте. При помощи метода сравнительного анализа определены особенности и общность объемно - пространственной организации сакральных сооружений мировых религий. Научная новизна. Определены общие черты архитектуры христианских, мусульманских и иудейских сакральных сооружений, а также смысловая нагрузка их отдельных форм и элементов с точки зрения религиозно-сакральных положений. Выводы. На основе изученного исторического и современного опыта проектирования и строительства христианских, мусульманских и иудейских сакральных сооружений, определены общие черты архитектурной композиции (объемнопространственных решений), а также смысловая нагрузка их архитектурных фрорм, вытекающая из религиозной догматики.

Ключевые слова: сакральное (культовое) сооружение, каноничность, символика форм, символ.

Zhovkva Olha, Doctor of Architecture, docent, chief specialist of Urban Development and Architecture Department, the Kyiv City State Administration

The symbolism of the sacred objects of world religions

Purpose of the article. The objective of the paper is to reveal the spiritual and religious content of the sacred constructions of world religions (Christianity, Islam, Judaism) in the context of canonical and sacred religious requirements. Methodology. It is based on the use of the method of on-site investigation of domestic and foreign sacred constructions and on the historical method, which allowed us to study the development process in historical context. With the help of the method of comparative analysis, special and common aspects of the space organization of the sacred constructions of world religions were determined. Scientific novelty. General features of the architecture of the Christian, Muslim and Jewish sacred buildings, as well as the semantic charge of their single forms and elements are determined from the point of view of religious sacred positions. Conclusions. Based on the historical and contemporary experience of designing and building of the Christian, Muslim and Jewish sacral buildings, general features of the architectural composition (space solutions), as well as the semantic charge of their architectural forms, deriving from religious dogmatics are determined.

Key words: sacred (worship) construction, canonicity, the symbolism of forms, symbol.

Актуальність теми дослідження. Досить довгий час, у період атеїзму, в Україні тривала заборона на віру, сакральну архітектуру, мистецтво тощо. На сьогодні, коли наша держава знаходиться на шляху відродження втраченої за даний період духовності, необхідно поступово відновлювати перерваний досвід храмобудування, а також зважаючи на незначну кількість наукових робіт, активізувати дослідження щодо особливостей архітектури сакральних споруд світових релігій та їх символічного значення.

() Жовква О. І., 2020 
Аналіз основних досліджень. Дослідження спирається на роботи щодо загальнотеоретичних та практичних проблем розвитку сакральної архітектури Ю. С. Асєєва, І. В. Бондаренко, О. Г. Бойко, Т. В. Буличової, О. О. Горбик, Ю. Р. Диби, М. П. Кіби, Є. О. Котляра, В. В. Куцевича, О. О. Лесик, Г. К. Лоїка, О. В. Мер'є, Н. С. Мірошник, О. Л. Михайлишин, Л. П. Скорик, О. С. Слєпцова, В. В. Соченка, Л. Я. Чень, Г. В. Шевцової, М.Б.Яціва, О. Ф. Ященка та інших вчених. У дослідженнях зазначених вчених розглянуто питання формування архітектурно-художнього образу та планувальної організації сакральних споруд, допоміжних будівель і споруд сакральних комплексів, проведено їхню класифікацію, наведено характеристики композиційних рішень, однак не приділено необхідної увагу питанням тлумачення символіки архітектурно-просторових рішень, форм та елементів сакральних споруд світових релігій.

Мета дослідження - дослідити символіку архітектурних форм та окремих елементів християнських, мусульманських та іудейських сакральних споруд, оскільки символ та символічність посідають важливе місце в культовій архітектурі.

Наукова новизна - запропоновано принцип релігійної гармонійності та канонічності архітектурної композиції християнських, мусульманських та іудейських сакральних споруд, застосування якого при проектуванні дозволить отримати гармонійні та канонічні з релігійної точки зору рішення.

Виклад основного матеріалу. Збереження історичної та культурної спадщини - це надзвичайно важливе завдання для кожної держави. Сакральні споруди різних періодів формують архітектурне обличчя міста, надаючи йому індивідуальний та неповторний характер. На жаль, в Україні досить довгий час тривав період атеїзму, під час якого руйнувались пам'ятки архітектури, відбувалась стагнація розвитку сакральної архітектури та мистецтва, що призвело до суттєвих втрат у вітчизняній культурі. Сьогодні в Україні відбувається процес відродження втраченої культурної та сакральної спадщини; зводяться нові культові споруди та комплекси для представників різних релігій (оскільки Україна є поліконфесійною державою) тощо. Ґрунтовні дослідження щодо проектування сакральних споруд та комплексів почали проводитись вітчизняними вченими на початку 90-х років минулого століття. Однак сьогодні дане питання висвітлено не в повній мірі: у проведених дослідженнях не приділено достатньої уваги питанню канонічного значення окремих форм та приміщень; організації внутрішнього простору; застосуванню символіки; можливому співіснуванню сакральних споруд та комплексів різних релігій тощо. Вирішення даних питань потребує проведення додаткових наукових досліджень та більш детального вивчення.

Дане дослідження базується на матеріалах, отриманих у ході натурних обстежень сакральних споруд України та зарубіжжя, а також на інформації, наданій під час бесід із духовенством та при здійсненні порівняльного аналізу вітчизняного та закордонного досвіду проектування культових споруд.

При проектуванні сакральних споруд і комплексів світових релігій, пропонується застосовувати принцип релігійної гармонійності, який полягає у використанні канонічних (таких, що не суперечать канонам тієі чи іншої релігії) архітектурних форм, а також синтезу мистецтв та національних традицій при вирішенні архітектурного образу, пам'ятаючи, що архітектура сакральної споруди - це втілення певної моделі світосприйняття та світотворення і змістове навантаження тут мають як окремі форми і деталі, так і конструкції, будівельні матеріали, інтер'єрне оздоблення тощо.

Так, християнські храми візантійської традиції зазвичай хрестовокупольні, в основу їхньої планувальної схеми покладено квадрат (або хрест із рівними кінцями). В архітектурній композиції сакральних споруд православної конфесії необхідно виявляти основний кубічний об'єм із куполом та декоративними банями. Купол у християнській культовій архітектурі (а також мусульманській та іудейській) символізує небо. Сам храм, здебільшого кубічної фрорми, - землю [2, 16]. Християнським храмам, як правило, властиві три символічні фрорми плану - квадрат, або прямокутник (символізує корабель), хрест і коло. Побудова храму у формі хреста нагадує, що даний символ є основою Християнської Церкви. Коло, покладене в основу планувальної схеми храмів-ротонд, є символом вічності, безмежності всесвіту.

Склепінчастий перехід всередині споруди, від основного об'єму до циліндру (барабану), називається «вітрилами» $[4,48]$. Стовпи, що підтримують центральне склепіння, символізують «Стовпи Церкви» - святих, на яких вона тримається. Верхня частина храму, зазвичай, складається з основи, барабана («шиї») і купола, над яким також може бути маківка із хрестом. Купол над центральним барабаном храму є засобом апофатичного вираження Бога та його центральної, трансцендентної позиції. Богословське поняття «око склепіння» у структурі сакральної споруди може передаватись через вікна, що символізують очі храму.

Маківка (завершення сакральної споруди) - це символ полум'я, вогню і, відповідно, вогняних небесних Сил. Символічне значення у сакральній споруді має кількість глав. Так, одна означає єдність Бога; три - знак святої Трійці; чотири - символізує чотирьох Євангелістів, або чотири сторони світу; п'ять глав означають Ісуса Христа та чотирьох Євангелістів; сім - знаменують сім таїнств Церкви, сім Вселенських Соборів; дев'ять - пов'язані з образом Пресвятої Богородиці; тринадцять глав знаменують Ісуса Христа і дванадцять Апостолів. Вибір кількості глав зазвичай залежить від присвяти храму 
(Трійці, Богородиці тощо) [8, 53]. У мусульманській сакральній архітектурні перевагу надають числу 4, акцентуючи таким чином просторову зорієнтованість культової споруди на чотири сторони світу.

Сакральна символіка (хрести, півмісяці, гексограми) повинні бути логічним продовженням конструкції сакрального об’єкта, завершенням та символом релігійної приналежності (до Християнства, Ісламу, Іудаїзму).

Що ж до християнських культових будівель західного обряду, то католицькі культові споруди римської традиції - це зазвичай базиліки, які можуть мати у плані фрорму латинського або грецького хреста. В основу побудови планувальних і просторових структур, їхніх окремих частин, також закладено релігійні значення та символіку. Так Св. Августин вважав, що назва (молитовний зал) католицької сакральної споруди уособлює собою тіло, а головний вівтар - серце та душу [9, 25]. Організація внутрішнього простору повинна бути підпорядкована поздовжній осі й базуватися на образі старозаповітного храму - скинії, символізуючи шлях до Бога або корабель.

Оригінальним доробком римської школи, який доречно використовувати в проектній практиці і сьогодні, можна вважати чотири найбільш розповсюджені типи планувальної структури католицького храму: центрична на основі кола; центрична хрестовокупольна; повздовжня традиційно-базилікальна; поздовжня базилікально - купольна (єзуїтська) [5, 9].

Символіка форм в архітектурі протестантських сакральних споруд не так важлива, оскільки церквою може бути будь-яка будівля, придатна для проведення богослужінь із залом для зібрань [11, 20]. Сучасна протестантська сакральна споруда стала більш функціональною, а символіка формоутворення, канон та стиль переважно пов'язані з її унітарним призначенням [6, 50].

Відповідно до мусульманської традиції, архітектурну композицію дворової мечеті (арабський тип) запровадив сам пророк Мухамед $[8,19]$. Загалом, можна виділити такі типи мечетей, як дворовий, центральнокупольний, багатозальний (багатокупольний), однозальний. Мечеті зазвичай мають покрівлю, що спирається на колони, за аналогією із православним храмобудівництвом, оскільки будівництво перших мечетей базувалось на візантійській архітектурній традиції.

При будівництві сучасних мечетей можна використовувати базилікальну традицію будівництва сакральних споруд, у зв'язку з чим мечеть може мати форму куба із куполом. При переході від кубічної або прямокутної форми споруди до основи купола - кола, можна застосовувати "сталактити" - аналог візантійських "вітрил". Купол у сакральній архітектурі різних релігій та конфесій перейшов цивілізаційні кордони [8, 190]. Він і досі виконує організуючу містобудівну функцію і $є$ характерною ознакою культових споруд світових релігій, символом неба.

Таким чином, сучасна мусульманська мечеть може бути окремо розташованою кубічною будівлею з квадратною гіпостильною залою, перекритою напівсферичним куполом, із внутрішнім двориком, мінаретом - виразною вертикальною домінантою. Вертикаль у культовій архітектурі різних релігій (християнські дзвіниці, мусульманські мінарети) тлумачиться як зв'язок між різними «рівнями» буття - земним і небесним, зв'язок неба та землі.

За основу внутрішнього устрою іудейських культових споруд (синагог) взято конструкцію храму - скинії, однак для даних споруд не передбачено усталених архітектурних форм. Синагоги можуть мати кубічну форму, прямокутний план з сакральною зоною, нартексом і молитовним залом [1, 13; 7, 85]. Також допускається проектувати синагоги круглої в плані фрорми, що символізуватиме вічність. Купол в об'ємно-просторовій композиції синагоги символізує єдність земного простору (квадратної молитовної зали) із небесною сферою (підкупольним простором). Його зводять над головним архітектурним об'ємом, втілюючи, аналогічно християнській та мусульманській доктринам, ідею єдності земного та небесного.

Висновки. Таким чином, можна констатувати певну подібність об'ємно-просторової та планувальної структури сакральних споруд світових релігій, зокрема спільність у символічному навантаженні їх окремих фрорм та елементів, а також у тлумаченні їх значення з позицій релігійного канону, про що слід пам'ятати приступаючи до проектування сучасних сакральних споруд традиційних релігій світу.

\section{תimepamypa}

1. Бойко О. Г. Архітектура мурованих синагог Правобережної України XVI-XX ст.: дис. ... канд. архіт.: 18.00.01. Львів: Нац. ун-т «Львівська політехніка», 2010. 20 с.

2. Будур Н. Православный храм. М.: РОССА, 2009. 271 с.

3. Вагнер Г. К. Канон и стиль в древнерусском искусстве. М.: Искусство, 1987. 223 с.

4. Гнідець Р. Архітектура українських церков. Конструкція і форма: навч. посіб. 2-ге вид., випр. і доп. Львів: Вид-во ун-ту «Львівська політехніка», 2009. 144 с.

5. Горбик О. О. Стильові риси провінційного католицького барокового храму (на прикладі костьолів Київщини і Волині): автореф. дис. ... канд. архіт.: 18.00.01. К.: Київський нац. ун-т буд-ва і архіт., 2003.20 с.

6. . Культові будинки та споруди різних конфесій: посіб. з проектув. / За ред. В. В. Куцевича. К.: КиївЗНДІЕП, 2002. 117 с.

7. Православные храмы: в 3 т. М.: ГУП ЦПП, 2003. Т. 2: Православные храмы и комплексы: Пособие по проектированию и строительству (к СП 31-103-99). МДС 31-9.2003 / АХЦ Арххрам. 222 с.

8. Шукуров Ш. М. Архитектура современной мечети: Истоки. М.: Прогресс-Традиция, 2014. 232 с. 
9. Aurelius Augustinus The Works: A Translation for the 21st Century. - New City Press, 1997. 452 p.

10. Hasan Uddin Khan International style Modernist Architecture from 1925 to 1965. ITALY: TASCHEN, 2001.

240 p.

11. PHILIP JOPIDIO New forms architecture in the 1990 s. ITALY: TASCHEN, 2001. 240 p.

\title{
References
}

1. Boyko, O.G. (2010). Architecture of Stone Synagogues of Right-Bank Ukraine of the 16th-20th Centuries, Abstract of the thesis for the degree of Candidate of Architecture, Lviv [in Ukrainian].

2. Budur, N. (2009). Orthodox Temple. Moscow: ROSSA [in Russian].

3. Vagner G. K. (1987). Canon and style in the Ancient Russian art. M.: Art [in Russian].

4. Hnidets R. (2009). The architecture of. Ukrainian churches. Structure and form: manual 2nd edition, amended and modified. Lviv: Publishing house of the University «Lvivska politehnika» [in Ukrainian].

5. Gorbyk O. O. (2003). Stylistic features of provincial Catholic baroque temple (based on the examples of the Roman Catholic churches in Kyiv and Voly regions): summary of PhD thesis in architecture: 18.00.01. K.: Kyiv national University of Construction and Architecture [in Ukrainian].

6. Kutsevich, V.V. (2002). Religious Buildings and Structures of Various Denominations: Design Guidebook. Kiev: KievZNIIEP [in Ukrainian].

7. Orthodox churches: in 3 b. M.: GUP CPP (2003). V. 2: Orthodox churches and complexes: design and construction manual (to SP 31-103-99). MDS 31-9.2003 / AHC «Arhhram» [in Russian].

8. Shukurov, Sh.M. (2014). Architecture of a Modern Mosque. Origins. Moscow: Progress - Tradition [in Russian].

9. Aurelius Augustinus (1997). The Works: A Translation for the 21st Century. - New City Press [in English].

10. Hasan Uddin Khan (2001). International style Modernist Architecture from 1925 to 1965. - ITALY: TASCHEN [in English].

11. PHILIP JOPIDIO (2001). New forms architecture in the 1990 s. - ITALY: TASCHEN [in English].

Стаття надійшла до редакції 25.10.2019 p. Прийнято до публікації 14.11.2019 р.

\section{Клековкін Олександр Юрійович}

доктор мистецтвознавства, професор, завідувач відділом теорії та історії культури Інституту проблем сучасного мистецтва Національної академії мистецтв України

ORCID 0000-0002-3481-2790 olehander@gmail.com

\section{ПЕРІОДИЗАЦІЯ І МЕТОД ІСТОРІЇ ТЕАТРУ: МАРКЕРИ}

\begin{abstract}
Мета роботи: виявити маркери методу дослідження на основі аналізу періодизацій, запропонованих українськими істориками театру XX століття проаналізувавши не дати, на які вони спиралися, а мотиви, якими вони керувалися. Методологія: порівняльний аналіз періодизацій історії українського театру і виокремлення в них ключових термінів, котрі виконують роль маркерів методу театрознавчого дослідження. Наукова новизна полягає в тому, що вперше одиницею аналізу принципів періодизації, як маркера методу дослідження, обрано терміни, якими оперували самі історики театру. Висновки: В історіографії українського театру виокремлено кілька типів періодизацій як маркера методу дослідження: І. Публіцистичний: а) епонімічний ("театр до Котляревського", "театр до Кропивницького" та ін.); b) канонічний, орієнтований на створення канону української культури; c) "накопичувальний" (накопичення "досягнень"); d) до темпорального накопичення "позитивних ознак" відносяться періодизації на основі термінів "старий", "новий", "новітній". II. Естетичний (частково за епонімами). III. Культурно-історичний: а) етноцентричний - акцентування інкультурації театру і визначення його місця у національній культурі; b) культурно-історичний з вкрапленням додаткових ознак IV. Проблемний: виокремлення локальних історичних сюжетів і деміфрологізація подій.
\end{abstract}

Ключові слова: історія театральної культури; періодизація історії театру; методологія театрознавства; маркери методу.

Клековкин Александр Юрьевич, доктор искусствоведения, профессор, заведующий отделом теории и истории культуры Института проблем современного искусства Национальной академии искусств Украины Периодизация и метод истории театра: маркеры

Цель работы: выявить маркеры методы исследования на основе анализа периодизаций, предложенных украинскими историками театра XX столетия, проанализировав не даты, на которые они опирались, а мотивы, которыми они руководствовались. Методология: сравнительный анализ периодизаций истории украинского театра и выделение в них ключевых терминов, которые выполняют роль маркеров метода театроведческого исследования. Научная новизна заключается в том, что единицей анализа принципов периодизации, как опосредованного индикатора метода исследования, избраны термины, которыми оперируют сами историки театра. Выводы: В историографии украинского театра выделено несколько типов периодизаций как маркера метода

( С Клековкін О. Ю., 2020 